\title{
PERFORMAN AYAM SENTUL FASE DEVELOPER YANG DIBERI BERBAGAI TINGKAT TEPUNG KUNYIT ( Curcuma domestica, Val) SEBAGAI IMBUHAN PAKAN
}

\author{
R. Wiradimadja ${ }^{1 a}$, T. Widjastuti ${ }^{2}$, D. Rusmana ${ }^{1}$, dan Abun ${ }^{1}$ \\ ${ }^{1}$ Departemen Nutrisi Ternak dan Teknolgi Pakan, Fakultas Peternakan Unpad. \\ ${ }^{2}$ Departemen Produksi Ternak, Fakultas Peternkan Unpad. \\ aemail : rachmatwr@gmal.com
}

\begin{abstract}
Abstrak
Penelitian ini dilaksanakan di kandang Test Farm Fakultas Peternakan Universitas Padjajaran, dengan tujuan untuk mengetahui pengaruh penambahan tepung kunyit (Curcuma domestica Val) dalam ransum sebagai feed aditif terhadap performan ayam Sentul periode developer. Penelitian ini mengunakan 60 ekor ayam sentul betina umur 16 minggu yang ditempatkan ke dalam 20 unit kandang dan tiap kandang terdiri dari 3 ekor. Metoda percobaan adalah eksperimen menggunakan Rancangan Acak Lengkap, terdiri atas empat perlakuan ransum dengan lima ulangan. Perlakuan terdiri dari $\mathrm{R}_{0}=$ Ransum basal, $\mathrm{R}_{1}=$ Ransum basal ditambah tepung kunyit $0,1 \%, R_{2}=$ Ransum basal ditambah tepung kunyit $0,2 \%$ dan $R_{3}=$ Ransum basal ditambah tepung kunyit $0,3 \%$. Peubah yang diamati adalah konsumsi ransum, umur pertama bertelur, dan bobot ayam saat pertama bertelur. Hasil analisis statistik menunjukkan bahwa penambahan tepung kunyit dalam ransum memberikan pengaruh yang nyata terhadap konsumsi ransum, bobot badan awal bertelur dan umur dewasa kelamin. Kesimpulan dari penelitian adalah penambahan tepung kunyit hingga $0,3 \%$ dapat diberikan pada ransum ayam Sentul periode developer sebagai feed additive.

Kata Kunci : Ayam sentul, imbuhan pakan, periode developer, performan, tepung kunyit.

\section{PERFORMANCE OF SENTUL CHICKENS PHASE DEVELOPER CONTAINING TUMERIC MEAL (Curcuma domestica, Val) IN THE RATION AS FEED ADITIVE}

\begin{abstract}
This research has been conducted at Local Chicken Breeding and Production Station, Laboratory of Poultry Production, Faculty of Animall Husbandry, Padjadjaran University, with the aim to know the effect of addition of turmeric meal (Curcuma domestica Val) in ration as feed additive on performance Sentul chicken period of developer. Sixty female chickens at 16-weeks-of age were raised into 20 units of cages and each cage consists of 3 female sentul. The experimental conducted with Completely Randomized Design, consisting of four ration treatments with five replications. The treatment consisted of $\mathrm{R} 0=$ Basal ration, $\mathrm{R} 1=$ Basal ration plus turmeric meal $0.1 \%, \mathrm{R} 2=$ Basal ration plus turmeric meal $0.2 \%$ and $\mathrm{R} 3=$ Basal ration plus turmeric meal $0.3 \%$. The variables observed were feed consumption,egg weight, age maturity, and maturity body weight. The result of statistical analysis showed that the addition of turmeric mean in ration gave significant effect on feed consumption, significantly different to maturity body weight and age maturity. The conclusion from this research is the addition of turmeric meal until $0.3 \%$ can be given in Sentul chicken ration of developer period as feed aditive.
\end{abstract}

Keywords : Sentul chicken, feed aditive, developer period, performance, turmeric meal. 


\section{Pendahuluan}

Ayam Sentul merupakan ayam yang berasal dari Ciamis Jawa Barat dan merupakan ayam asli Indonesia. Ayam Sentul merupakan ayam tipe dwi guna yang memiliki bobot badan dan memproduksi telur tinggi, selain itu ayam sentul juga mempunyai pertumbuhan yang relatif cepat dibandingkan dengan ayam lokal biasa. Sebagai sumberdaya genetik ternak Jawa Barat, ayam sentul memiliki prospek yang baik untuk dikembangkan sebagai ayam kampung yang dipelihara secara semiorganik.

Fase Developer ayam petelur umur 1218 minggu, yakni fase perkembangan yang ditandai dengan pertumbuhan anatomi kerangka ayam dan otot (daging) yang lebih dominan (Fadilah dan Fatkhuroji, 2013). Periode grower/developer, terjadi perkembangan ukuran sel (hipertrofi). Dalam fase ini, terjadi perkembangan pada kerangka tubuh sampai mencapai bentuk sempurna. Periode grower memiliki 3 waktu kritis yang harus diperhatikan, yaitu pada umur 6-7 minggu, 12 minggu, dan 14 minggu. Antara minggu ke-6 dan ke-7 adalah puncak perkembangan kerangka tubuh (frame size), 80\% frame size sudah mencapai dimensi akhir (Adlan et al., 2012). Perkembangan kerangka tubuh minggu ke-12 telah mencapai puncaknya sehingga setidaknya ada dua hal yang perlu diperhatikan peternak, yaitu mengejar ketinggalan frame size (berat badan) sebelum minggu ke-12 dan mempertahankan berat tubuh yang sudah sama atau $10 \%$ di atas standar untuk menghadapi masa awal bertelur. Selain tercapainya berat tubuh yang sesuai dan perkembangan frame size yang optimal, tingkat keseragaman ayam juga perlu untuk tetap diperhatikan (Adlan et al., 2012). Hal penting lainnya dalam pemeliharaan fase developer adalah harus memperhatikan konsumsi ransum per hari, baik dari segi kualitas maupun kuantitasnya.

Salah satu cara untuk menjadikan ransum dapat dimanfaatkan secara efisien yaitu dengan pemberian antibiotik untuk mencapai perkembangan frame size yang optimal dan tidak keseragaman bobot tubuh, akan tetapi penggunaan antibiotik terus-menerus dengan dosis yang tidak tepat ternyata berdampak timbulnya resistensi pada mikroorganisme tertentu di dalam tubuh ayam sehingga mengganggu kesehatannya. Upaya yang dapat dilakukan untuk menghindari efek negatif tersebut adalah dengan pemberian imbuhan pakan (feed additive) alami pengganti antibiotik. Salah satunya adalah melalui pemanfaatan tanaman herbal seperti tepung kunyit (Curcuma domestica $\mathrm{Val}$ ).

Kunyit yang mempunyai berbagai nama daerah yang berbeda-beda diantaranya : Sumatra ; Kakunye (Enggano), Kunyet (Adoh), Kuning (Gayo), Kunyet (Alas), Hunik (Batak), Odil (Simalur), Undre, (Nias), Kunyit (Lampung), Kunyit (Melayu). Jawa : Kunyir (Sunda) (Roihatul, 2015), merupakan salah satu tanaman herbal yang dapat digunakan sebagai pakan tambahan dan nmemiliki kualitas yang baik apabila ditambahkan ke dalam ransum untuk ungags (Pratikno, 2010). Kunyit (Curcuma domestica $\mathrm{Val}$ ) dapat digunakan sebagai pemacu pertumbuhan dan imunomodulator atau antibakteri pada ternak unggas. Tepung kunyit memiliki kandungan air sebesar $14,57 \%$, protein sebesar $8,39 \%$, lemak sebesar $2,84 \%$, serat kasar sebesar 10,85\%, abu sebesar $8,32 \%$ dan karbohidrat sebesar 54,96\% (Jarwati, 1998). Kandungan kurkuminoid dalam kunyit sebesar 3-5 \% dan ,engandung minyak atsiri (Abbas dan Lichtman, 2004). Adanya zat kurkumin dalam kunyit menyebabkan adanya daya hambat antibakteri yang cukup kuat, dan memacu pertumbuhan serta meningkatkan efisiensi pakan dengan mengurangi mikroorganisme pengganggu atau meningkatkan populasi mikroba yang menguntungkan, yang ada dalam saluran pencernaan ayam sehingga efisiensi penggunaan pakan akan meningkat (Bintang dan Nataamijaya, 2005). Minyak atsiri yang terkandung dalam kunyit dapat membantu pencernaan dengan merangsang sistem saraf sekresi sehingga keluar getah lambung yang mengandung enzim seperti pepsin, trypsin, lipase, amylase disekresikan ke dalam lambung dan usus sehingga diharapkan dapat meningkatkan metabolisme zat-zat makanan (Abbas dan Lichtman, 2004).

Adanya zat aktif kurkumin dan minyak atsiri berpengaruh cukup besar terhadap aktivitas antimikroba, Semakin tinggi dosis yang diberikan maka semakin meningkat kandungan 
zat aktifnya. Namun disisi lain terdapat kendala karena bau dan rasa dari tepung kunyit yang tidak disukai oleh ayam sentul. Oleh karena itu, diperlukan batasan-batasan dalam pemberiannya.. Hasil penelitian Mide (2007), pemberian kunyit dalam ayam broiler dengan dosis $0,01 \%, 0,02 \%$ dan $0,04 \%$ dalam ransum, ternyata semakin tinggi dosis pemberian semakin menurunkan konsumsi ransum. Adanya efek minyak atsiri terhadap fungsi atau kerja saluran pencernaan khususnya usus halus dan bersifat racun pada dosis yang berlebihan, maka penggunaan kunyit yang tepat diharapkan mampu meningkatkan metabolisme tubuh dan metabolisme yang mempengaruhi sel-sel saluran pencernaan. Penelitian ini dilaksanakan untuk mempelajari efek dari penambahanan tepung kunyit dalam ransum sebagai imbuhan pakan (feed additive) untuk pengganti antibiotik terhadap performan ayam sentul fase developer yang dipelihara semi organik (tanpa vaksinasi dan obat-obatan).

\section{Bahan dan metode}

Penelitian dilakukan selama 16 minggu, dilaksanakan di kandang Test Farm, Fakultas Peternakan Universitas Padjadjaran. Penelitian menggunakan 60 ekor ayam Sentul betina umur 16 minggu dengan bobot awal relatif seragam $(1,408 \pm 123 \mathrm{~g})$, yang ditempatkan secara acak pada 20 petak kandang litter berukuran 1 x 1 meter untuk 3 ekor.
Ransum yang digunakan dalam penelitian disusun berdasarkan kebutuhan ayam petelur fase grower/developer dengan kandungan protein $15 \%$ serta energi metabolis $2700 \mathrm{kkal} / \mathrm{kg}$. Kandungan nutrien dan energi metabois baha penyusun ransum disajikan pada Tabel 1.

Susunan ransum basal yang digunakan terdiri atas tepung ikan (8\%), bungkil kedelai $(4,75 \%)$, jagung kuning (58\%), dedak halus $(28 \%), \mathrm{CaCO}_{3}(0,50 \%)$, dan tepung tulang $(0,75 \%)$. Untuk kandungan nutriennya adalah sebagai berikut : Protein (15\%), Lemak (6,66\%), Serat Kasar $(4,89 \%$, Ca $(1,05 \%)$, Phosfor $(0,58 \%)$, Lisin $(0,97)$, Metionin $(0,35 \%)$, dan Energi Metabolis (2755 kkal/kg).

Perlakuan yang diberikan adalah tingkat penambahan tepung kunyit, yaitu $0 \%, 0,1 \%$, $0,2 \%$, dan $0,3 \%$ Peubah yang diamati meliputi konsumsi ransum, umur pertama bertelur, dan bobot ayam saat pertama bertelur. Metode percobaan yang digunakan Rancangan Acak Lengkap dengan 4 perlakuan ransum yang mengandung tingkat tepung kunyit, dan diulang lima kali dan setiap ulangan terdiri atas 3 ekor pullet ayam Sentul. Data yang diperoleh dianalisis dengan menggunakan Sidik Ragam dan dilanjutkan dengan uji Duncan untuk membandingkan antar perlakuan (Steel dan Torrie, 1980).

Tabel 1. Kandungan Nutrien dan Energi Metabolis Bahan Pakan Penyusun Ransum

\begin{tabular}{|c|c|c|c|c|c|c|c|c|c|}
\hline \multirow[b]{2}{*}{ Bahan Pakan } & PK & LK & SK & $\mathrm{Ca}$ & $\mathrm{P}$ & Lisin & Met & Sist & \multirow{2}{*}{$\frac{\text { EM }}{(\mathrm{kkal} / \mathrm{kg})}$} \\
\hline & \multicolumn{8}{|c|}{. } & \\
\hline Tepung ikan & 58,0 & 9,00 & 1,00 & 7,70 & 3,90 & 6,50 & 1,80 & 0,90 & 2970 \\
\hline Bungkil kedelai & 44,0 & 0,90 & 6,00 & 0,32 & 0,29 & 2,90 & 0,65 & 0,67 & 2240 \\
\hline Jagung kuning & 8,60 & 3,90 & 2,00 & 0,02 & 0,10 & 0,20 & 0,18 & 0,18 & 3370 \\
\hline Dedak halus & 12,0 & 13,00 & 12,00 & 0,12 & 0,21 & 0,71 & 0,27 & 0,37 & 1630 \\
\hline $\mathrm{CaCO} 3$ & 0,00 & 0,00 & 0,00 & 40,00 & 0,00 & 0,00 & 0,00 & 0,00 & 0 \\
\hline Tepung tulang & 0,00 & 0,00 & 0,00 & 23,30 & 18,00 & 0,00 & 0,00 & 2 & 0 \\
\hline Tepung kunyit & 8,39 & 2,84 & 10,85 & 0 & 0 & 0 & 0 & 0 & 0 \\
\hline
\end{tabular}

Sumber : Hasil analisis Laboratorium Nutrisi Ternak Ruminansia dan Kimia Makanan Ternak, Fakultas Peternakan,Universitas Padjadjaran, 2016.

Keterangan : $\mathrm{PK}=$ Protein Kasar; $\mathrm{LK}=$ Lemak Kasar; $\mathrm{SK}=$ Serat Kasar; $\mathrm{Ca}=$ Calsium; $\mathrm{P}=$ Phosfor; Met $=$ Metionin; Sist $=$ Sistein $; \mathrm{EM}=$ Energi Metabolis . 


\section{Hasil dan Pembahasan}

\section{Pengaruh Perlakuan Terhadap Konsumsi Ransum}

Rataan konsumsi ransum ayam sentul selama penelitian disajikan pada Tabel 2.

Tabel 2. Pengaruh Perlakuan Terhadap Konsumsi Ransum

\begin{tabular}{|c|c|c|c|c|}
\hline \multirow{2}{*}{ Ulangan } & $\mathrm{P}_{0}$ & $\mathrm{P}_{1}$ & $\mathrm{P}_{2}$ & $\mathrm{P}_{3}$ \\
\hline & \multicolumn{4}{|c|}{ 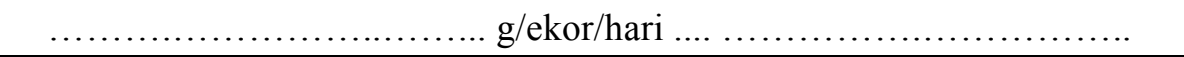 } \\
\hline 1 & 72,54 & 69,96 & 69,08 & 69,92 \\
\hline 2 & 75,87 & 76,12 & 74,62 & 70,92 \\
\hline 3 & 76,83 & 69,00 & 71,00 & 74,50 \\
\hline 4 & 75,71 & 68,62 & 69,29 & 71,75 \\
\hline 5 & 75,96 & 75,21 & 72,96 & 69,87 \\
\hline Rataan & $75,38 \mathrm{~b}$ & $71,78 \mathrm{a}$ & $71,79 \mathrm{a}$ & $71,39 \mathrm{a}$ \\
\hline
\end{tabular}

Keterangan : $\mathrm{P}_{0}=$ ransum basal tanpa penambahan tepung kunyit

$\mathrm{P}_{1}=$ ransum basal $+0,1 \%$ tepung kunyit

$\mathrm{P}_{2}=$ ransum basal $+0,2 \%$ tepung kunyit

$\mathrm{P}_{3}=$ ransum basal $+0,3 \%$ tepung kunyit

Rataan konsumsi ransum pada berbagai perlakuan berkisar antara 71,39 g sampai dengan 75,38 g per ekor per hari. Tabel 3 menunjukkan bahwa pemberian ransum dengan berbagai level tepung kunyit konsumsi ransumnya cenderung menurun. Terlihat bahwa penambahan tepung kunyit dalam ransum pada perlakuan $\mathrm{P}_{1}(0,1 \%), \mathrm{P}_{2}(0,2 \%)$ dan $\mathrm{P}_{3}(0,3 \%)$ konsumsi ransum nyata $(\mathrm{P}<0.05)$ lebih rendah dibandingkan dengan perlakuan tanpa penambahan tepung kunyit $\left(\mathrm{P}_{0}=0 \%\right)$, walaupun ransum dibuat dengan kandungan tingkat protein dan energi yang sama. Hal ini Sejalan dengan pendapat yang dikemukakan Bintang dan Nataamijaya (2005) bahwa penambahan tepung kunyit untuk level yang lebih tinggi dapat menurunkan palatabilitas ransum sehingga kemampuan ternak dalam mengkonsumsi ransum akan berkurang. Keadaan ini dapat terjadi karena kunyit mengandung minyak atsiri dengan bau yang khas dan rasa pahit sehingga mengurangi nafsu makan. Sesuai dengan pendapat Scott et al. (1982) bahwa jumlah ransum yang dikonsumsi juga dipengaruhi oleh palatabilitas ransum. Semakin ransum palatabel maka semakin banyak jumlah ransum yang dikonsumsi.

\section{Pengaruh Perlakuan Terhadap Bobot Badan}

Pemberian tepung kunyit level $0,1-0,3$

$\%$ dalam ransum menghasilkan bobot badan cenderung lebih rendah. Hal ini disebabkan oleh penurunan konsumsi ransum. Hasil Penelitian Patri et al. (2014) membuktikan bahwa penambahan tepung rimpang kunyit, dan tepung rimpang temulawak sebanyak $2 \%$ dalam ransum komersial tidak meningkatkan konsumsi ransum, produksi telur dan menekan konversi ransum. Namun, Liang et al. (1985) melaporkan bahwa kandungan zat kimia kunyit (kurkumin) dalam tubuh ayam juga berperan dalam penurunan lemak sehingga terjadi pula penurunan bobot hidup pada ayam.

Hasil sidik ragam menunjukkan bahwa penambahan tepung kunyit pada berbagai level sebagai feed aditive pada ransum basal memberikan pengaruh yang nyata $(\mathrm{P}<0,05)$ terhadap bobot badan. Hal ini menunjukkan bahwa konsumsi ransum dengan penambahan tepung kunyit dalam ransum semakin menurunkan bobot badan. Keadaan ini karena masa periode developer ayam petelur terjadi penurunan bobot badan setelah mencapai bobot badan maksimal tetapi konsumsi ransum terus meningkat. Sejalan dengan pendapat Ruhyat dan Edjeng (2010) bahwa kecepatan pertumbuhan ayam yang masih muda umurnya akan tinggi dan akan menurun setelah mencapai bobot badan maksimum. Adanya perbedaan kecepatan pertumbuhan berdasarkan umur maka masa pertumbuhan pada ayam petelur dibagi menjadi dua fase yaitu 6-14 minggu fase grower dan 1420 minggu disebut fase developer. Fase 
developer merupakan fase pertumbuhan yang sudah menurun, tetapi konsumsi ransum terus bertambah (Kartasudjana dan Edjeng, 2010).

Fase developer ayam petelur memang tidak menunjukkan kenaikan bobot badan yang signifikan, hal ini dikarenakan pada fase ini tidak mengalami perubahan fisik tetapi lebih mempersiapkan ke perkembangan organ-organ reproduksi. Sejalan dengan pendapat Rasyaf (1995) bahwa periode developer secara fisik tidak mengalami perubahan berarti, perubahan hanya dari ukuran tubuhnya yang semakin bertambah dan bulu yang semakin lengkap serta kelamin sekunder mulai nampak. Selama periode ini terjadi perkembangan ukuran dan terbentuknya rangka, perkembangan organ tubuh, perkembangan hormon. Pertumbuhan akan menyebabkan metabolisme protein dalam tubuh semakin baik yang akan berpengaruh juga pada pertambahan bobot badan. Hal ini sesuai dengan pendapat Harper et al. (1980) bahwa pepsinogen yang diaktifkan menjadi pepsin oleh $\mathrm{HCl}$ yang disekresi oleh sel-sel parietal akan melakukan pemecahan protein menjadi asam amino. Pepsin juga menimbulkan efek autokatalitik yang dapat menyebabkan pengaktifan pepsinogen yang masih tersisa.
Artinya, semakin banyak pepsin yang terbentuk sehingga menyebabkan pemecahan protein semakin baik yang berefek pada pertambahan bobot badan tinggi.

\section{Pengaruh Perlakuan Terhadap Umur Dewasa Kelamin}

Umur dewasa kelamin ayam Sentul betina ditandai dari pertama kali bertelur, dengan menghitung selisih hari antara ayam saat pertama kali bertelur dengan tanggal waktu menetas. Hasil pengamatan rataan umur dewasa kelamin ayam sentul setiap perlakuan dapat dilihat pada Tabel 4.

Hasil sidik ragam terlihat bahwa perlakuan penambahan tepung kunyit dalam ransum basal berpengaruh nyata $(\mathrm{P}<0.05)$ terhadap umur dewasa kelamin ayam sentul betina. Hasil uji jarak Duncan menunjukkan bahwa pemberian tepung kunyit sebanyak 0,2 sampai 0,3 persen menunjukkan perbedaan umur dewasa kelamin dibandingkan dengan perlakuan lain. Umur dewasa kelamin pada ayam sentul yang diberi tepung kunyit 0,2 sampai 0,3 persen dalam ransum basal jauh lebih lambat dibanding dengan perlakuan yang diberi 0,1 persen tepung kunyit dan tanpa diberi tepung kunyit.

Tabel 3. Pengaruh Perlakuan Terhadap Bobot Badan

\begin{tabular}{ccccc}
\hline \multirow{2}{*}{ Ulangan } & $\mathrm{P}_{0}$ & $\mathrm{P}_{1}$ & $\mathrm{P}_{2}$ & $\mathrm{P}_{3}$ \\
\cline { 2 - 5 } & $\ldots \ldots \ldots \ldots \ldots \ldots \ldots \ldots \ldots \ldots \ldots \ldots \ldots \ldots \ldots \ldots \ldots \ldots \ldots \ldots \ldots \ldots \ldots \ldots \ldots \ldots \ldots \ldots \ldots \ldots \ldots \ldots \ldots \ldots \ldots \ldots \ldots \ldots \ldots$ \\
2 & 1540 & 1460 & 1450 & $138 \ldots$ \\
3 & 1670 & 1600 & 1520 & 1530 \\
4 & 1560 & 1520 & 1540 & 1510 \\
5 & 1570 & 1480 & 1470 & 1480 \\
\hline Rataan & 1620 & 1430 & 1410 & $1474 \mathrm{a}$ \\
\hline
\end{tabular}

Keterangan : $\mathrm{P}_{0}=$ ransum basal tanpa penambahan tepung kunyit

$\mathrm{P}_{1}=$ ransum basal $+0,1 \%$ tepung kunyit

$\mathrm{P}_{2}=$ ransum basal $+0,2 \%$ tepung kunyit

$\mathrm{P}_{3}=$ ransum basal $+0,3 \%$ tepung kunyit 
Tabel 4. Pengaruh Perlakuan Terhadap Umur Dewasa Kelamin

\begin{tabular}{|c|c|c|c|c|}
\hline \multirow{2}{*}{ Ulangan } & $\mathrm{P}_{0}$ & $\mathrm{P}_{1}$ & $\mathrm{P}_{2}$ & $\mathrm{P}_{3}$ \\
\hline & \multicolumn{4}{|c|}{ 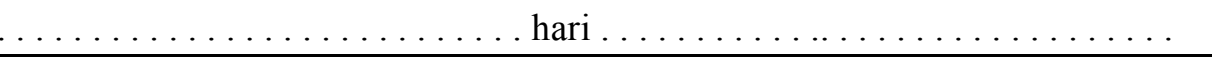 } \\
\hline 1 & 161 & 162 & 170 & 168 \\
\hline 2 & 165 & 165 & 161 & 167 \\
\hline 3 & 167 & 161 & 156 & 163 \\
\hline 4 & 162 & 162 & 171 & 165 \\
\hline 5 & 160 & 165 & 169 & 170 \\
\hline Rata-rata & $163 \mathrm{a}$ & $163 \mathrm{a}$ & $165,4 \mathrm{~b}$ & $166,6 \mathrm{~b}$ \\
\hline
\end{tabular}

Keterangan : $\mathrm{P}_{0}=$ ransum basal tanpa penambahan tepung kunyit

$\mathrm{P}_{1}=$ ransum basal $+0,1 \%$ tepung kunyit

$\mathrm{P}_{2}=$ ransum basal $+0,2 \%$ tepung kunyit

$\mathrm{P}_{3}=$ ransum basal $+0,3 \%$ tepung kunyit

Hal ini terjadi karena tepung kunyit mempunyai efek kolagoga yaitu merangsang sekresi cairan empedu sehingga dapat menurunkan kolesterol. Dinyatakan oleh Afifah (2003) bahwa meningkatnya produksi dan sekresi empedu, maka kolesterol keluar bersama feses, menyebabkan kolesterol darah dan tubuh menurun karena kolesterol merupakan salah satu bahan baku empedu.

Kunyit dan temulawak mempunyai aktivitas kolagoga (Afifah, 2003), sementara Widodo (2002), menyatakan bahwa dalam ramuan herbal khususnya temulawak dan kunyit dapat menurunkan kadar kolesterol tubuh juga bersifat hipokolesteremik. Telah diketahui bahwa fungsi kolesterol adalah sebagai prekursor hormon estrogen maupun testosteron sehingga dengan meningkatnya penggunaan tepung kunyit akan menurunkan aktifitas kolesterol dan berdampak menghambat kepada umur dewasa kelamin.

\section{SIMPULAN}

Hasil penelitian dapat disimpulkan bahwa penambahan tepung kunyit dalam ransum memberikan pengaruh yang nyata terhadap konsumsi ransum, bobot badan awal bertelur, dan umur dewasa kelamin. Penambahan tepung kunyit hingga 0,3\% dapat diberikan pada ransum ayam sentul periode developer sebagai feed additive.

\section{UCAPAN TERIMA KASIH}

Ucapan terima kasih disampaikan kepada Kepala Laboratorium Produksi Ternak Unggas, Departemen Produksi Ternak, Fakultas Peternakan Unversitas Padjadjaran, beserta seluruh pihak terkait yang telah memfasilitasi pelaksanaan penelitian ini.

\section{DAFTAR PUSTAKA}

Abbas AK, Lichtman AH. 2004. Basic Immunology: Functions and dissorders of the immune system. Ed. Ke-2. Philadelphia (US): Saunders.

Adlan, M., Y. Utomo, F. Afmy, dan N. Fitriany. 2012. Laporan Penilaian Ternak Unggas Ayam Petelur. Fakultas Peternakan. Universitas Jenderal Soedirman. Purwokerto.

Afifah, E. dan T. Lentera. 2003. Khasiat dan Manfaat Temulawak. Rimpang Penyembuh Aneka Penyakit. Cetakan 1. Agromedia Pustaka, Jakarta.

Bintang, I.A.K dan A.G. Nataamijaya. 2005. Pengaruh penambahan tepung kunyit (Curcuma domestica Val.) dalam ransum broiler.

http://peternakan.litbang.deptan.go.id/fullt eks/ semnas/pro05-103.pdf. (Pebruari 2018).

Fadilah, R. dan Fatkhuroji. 2013. Memaksimalkan Produksi Ayam Ras Petelur. PT AgroMedia Pustaka. Jakarta. 
Harper, et al. 1980. Biokimia Review of Physiological Chemistry. Edisi 17. EGC: Jakarta

$\mathrm{N}$,

Nhttp:/www.gudangmateri.com/2010/02/ biokimia-protein.html

Jarwati. 1998. Evaluasi penambahan temulawak (Curcuma xantorhriza, roxb) atau kunyit (Curcuma domestika, val) pada pakan terhadap daging domba ekor tipis. Skripsi. Jurusan Teknologi Industri Pertanian Fakultas Pertanian Institut Pertanian Bogor, Bogor.

Kartasudjana, R dan Edjeng, 2010. Manajemen Ternak Unggas. Penebar Swadaya. Jakarta.

Liang OB, Y. Widjaja , S. Puspa. 1985. Beberapa Aspek Isolasi, Identifikasi dan Penggunaan Komponen-Komponen Curcuma xanthorrhiza Roxb dan 28 Curcuma domestica Val. Prosiding Simposium Nasional.

Mide, M. Z. 2007. Konversi ransum dan income over feed and chick cost broiler yang diberi ransum mengandung berbagai level tepung rimpang temulawak (Curcuma xanthorrhiza Roxb). Buletin Nutrisi dan Makanan Ternak Vol. 6 (2): 21-26.

Patri, S. K., M. E. K Montong, C. L. K. Sarayar dan J. L. P. Saerang. 2014. Penambahan Rimpang Kunyit (Curcuma Domestica Val), Rimpang Temulawak (Curcuma xanthorriza Roxb) Dan Rimpang Temu Putih (Curcuma zedoaria Rosc) Dalam Ransum Komersial Terhadap Performans Burung Puyuh (Coturnix-coturnix japonica). Jurnal Zootek, Vol 34 No.11 : 114-123
Pratikno, H. 2010. Pengaru Ekstrak Kunyit (Curcuma domestica Vahl) Terhadap Bobot Badan Ayam Broiler (Gallus sp). Anatomi Fisiologi. Vol. 18 (2).

Rasyaf, M., 1995. Beternak Ayam Petelur. Jakarta: Penebar Swadaya.

Roihatul, M. 2015. Evidence Based Kurkumin dari Tanaman Kunyit (Curcuma longa) Sebagai Terapi Kanker pada Pengobatan Modern. Jurnal Farma Sains Vo. 1 (1) : 1. (pdf) [14/08/2018]

Scott, M.L.M.C. Nesheim and R.J. Young. 1982. Nutrition of the Chickens. Second Ed. M.L.Scott and Associates, Ithaca, New York

Steel, R.G.D. and J.H. Torries. 1980. Principles and Procedures of Statistics, A Biometrical Approach. International Student Ed.McGraw-Hill . Kogakusha Limited, Tokyo.

Widodo, W. 2002. Nutrisi dan Pakan Unggas Kontekstual. Proyek Peningkatan Penelitian Pendidikan Tinggi Direktorat Jenderal Pendidikan Tinggi Departemen Pendidikan Nasional, Jakarta. 